\title{
Cisplatin impairs fluid and electrolyte absorption in rat small intestine: a role for 5-hydroxytryptamine
}

\author{
C P Bearcroft, P Domizio, F H Mourad, E A André, M J G Farthing
}

\begin{abstract}
Background-The antineoplastic drug cisplatin has been widely used for the treatment of cancer in humans but its use has been limited by vomiting and diarrhoea. Cisplatin releases 5-hydroxytryptamine into the gut which is thought to be the major mediator of cisplatin induced vomiting.

Aim-To determine whether cisplatin affects fluid and electrolyte transport in rat jejunum and whether this change can be modulated by the 5-hydroxytryptamine receptor antagonist, ondansetron.

Methods-Jejunal perfusion in rats in vivo was performed one hour after intraperitoneal cisplatin ( 5 and $10 \mathrm{mg} / \mathrm{kg}$ ) administration. The effect of pretreatment with subcutaneous ondansetron $300 \mu \mathrm{g} / \mathrm{kg}$ was investigated.

Results-Median net fluid absorption after cisplatin $10 \mathrm{mg} / \mathrm{kg}(67 \mu 1 / \mathrm{min} / \mathrm{g}$ dry intestinal weight (interquartile range 46 to $100) ; n=15)$ was reduced compared with controls (120 (107 to 151$) \mu 1 / \mathrm{min} / \mathrm{g} ; \mathrm{n}=13$; $\mathrm{p}<0.001)$. Ondansetron reversed the impairment of jejunal fluid absorption produced by cisplatin to normal (161 (130 to 176) $\mu 1 / \mathrm{min} / \mathrm{g} ; \mathrm{n}=11 ; \mathbf{p}<0.001)$. Electrolyte movement paralleled fluid movement. Jejunal histological examination of sections from cisplatin treated animals showed villus damage, which was not prevented by pretreatment with ondansetron. Conclusion-These findings suggest that diarrhoea during cisplatin therapy may be due to altered fluid transport in the small bowel. The reversal of fluid transport to normal in the presence of a 5-hydroxy-

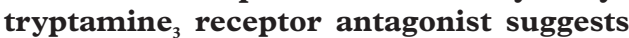
that 5-hydroxytryptamine is a local mediator in the small intestine.

(Gut 1999;44:174-179)
\end{abstract}

Digestive Diseases

Research Centre, St Bartholomew's and Royal London, School of Medicine and

Dentistry, Turner St, London E1 2AD, UK

C P Bearcroft

P Domizio

F H Mourad

E A André

M J G Farthing

Correspondence to:

Dr C P Bearcroft.

Accepted for publication 23 September 1998
Keywords: cisplatin; 5-hydroxytryptamine; rat; ondansetron; small intestine; fluid transport

The antineoplastic drug cisplatin (cisdiammine dichloroplatinum II) has been shown to be highly effective against a wide variety of cancers. Its use was initially limited by severe nausea and emesis, and $67 \%$ of patients also suffered from diarrhoea. ${ }^{1}$ Emesis was partially controlled by high dose metoclopramide when its effect was attributed to 5-hydroxytryptamine ${ }_{3} \quad\left(5-\mathrm{HT}_{3}\right) \quad$ receptor antagonism. ${ }^{2}$ Since then other more selective $5-\mathrm{HT}_{3}$ receptor antagonists have been developed, such as ondansetron and granisetron, which have been shown to reduce early cisplatin induced emesis considerably. ${ }^{3-5}$

5-HT has been implicated as a cause of diarrhoea in patients with carcinoid syndrome, and treatment with the $5-\mathrm{HT}_{3}$ receptor antagonist tropisetron has been shown to reduce the diarrhoea. ${ }^{6}$ Triple lumen perfusion in such patients has shown jejunal secretion of fluid, which could also be reduced by the $5-\mathrm{HT}_{1}$ receptor antagonist methysergide. ${ }^{7}$ In addition, 5-HT has been shown to be released during cholera toxin induced secretion in man and rats, ${ }^{89}$ and $5-\mathrm{HT}_{2}$ and $5-\mathrm{HT}_{3}$ receptor antagonism reverses cholera toxin induced secretion in rats and humans. ${ }^{10-12} 5-\mathrm{HT}$ is also released in morphine withdrawal induced intestinal secretion. ${ }^{13}$ After treatment with high dose cisplatin, increased 5-hydroxyindoleacetic acid (5-HIAA) was found in the urine of cancer patients ${ }^{414}$ and portal venous blood of laboratory animals in an in vitro study, ${ }^{15}$ indicating increased 5-HT release from the gut.

As cisplatin treatment is clinically associated with diarrhoea and 5-HT is known to be an intestinal secretagogue, ${ }^{16}{ }^{17}$ we investigated the effect of cisplatin on intestinal fluid and electrolyte movement in rat jejunum and the possible involvement of $5-\mathrm{HT}_{3}$ receptors by performing experiments with the $5-\mathrm{HT}_{3}$ receptor antagonist, ondansetron.

\section{Materials and methods}

SMALL INTESTINAL PERFUSION

After an overnight fast with free access to water, adult male Wistar rats (180-200 g) were anaesthetised with intraperitoneal pentobarbitone $(60 \mathrm{mg} / \mathrm{kg})$. A laparotomy was performed, and a $25 \mathrm{~cm}$ length of proximal jejunum was ligated such that this segment of small bowel was isolated with its blood supply intact. The isolated segment was then opened proximally and distally by $2-3 \mathrm{~mm}$ incisions on the antimesenteric border. The lumen of the segment was flushed with physiological saline at $37^{\circ} \mathrm{C}$ to remove any luminal contents and then air was injected to clear the small intestine of residual content. The segment was then cannulated at both ends and returned to the abdominal cavity and the abdomen was closed. Cisplatin (cis-diammine dichloroplatinum II), dissolved in $0.9 \%$ saline at $25^{\circ} \mathrm{C}$ at a concentration of $1 \mathrm{mg} / \mathrm{ml}$, was injected intraperitoneally at doses of 5 and $10 \mathrm{mg} / \mathrm{kg}$. Control animals were injected with the same volume of saline. At one hour after cisplatin

Abbreviations used in this paper: $5-\mathrm{HT}$, 5-hydroxytryptamine; 5-HIAA, 5-hydroxyindoleacetic acid; PEG, polyethylene glycol. HPLC, high performance liquid chromatography. 


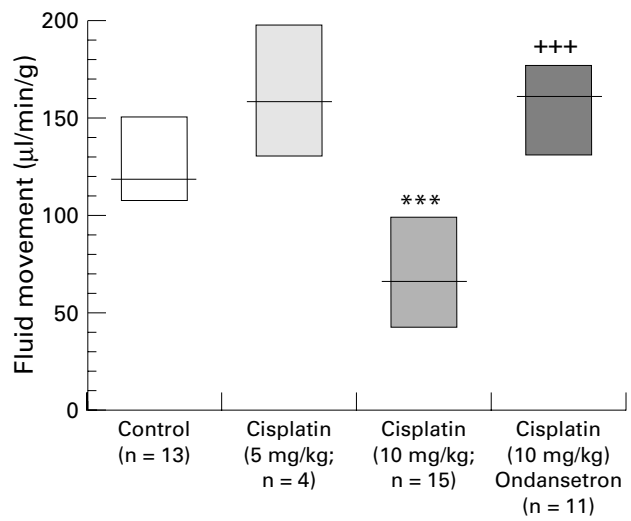

Figure 1 Net fluid movement $(\mu \mathrm{l} / \mathrm{min} / \mathrm{g})$ in controls and animals treated with cisplatin or cisplatin and ondansetron. Values are expressed as median (horizontal line) and interquartile range (bar). ${ }^{\star \star \star} p<0.001$ compared with controls; $+\dagger+p<0.001$ compared with cisplatin $10 \mathrm{mg} / \mathrm{kg}$ alone but no different from controls.

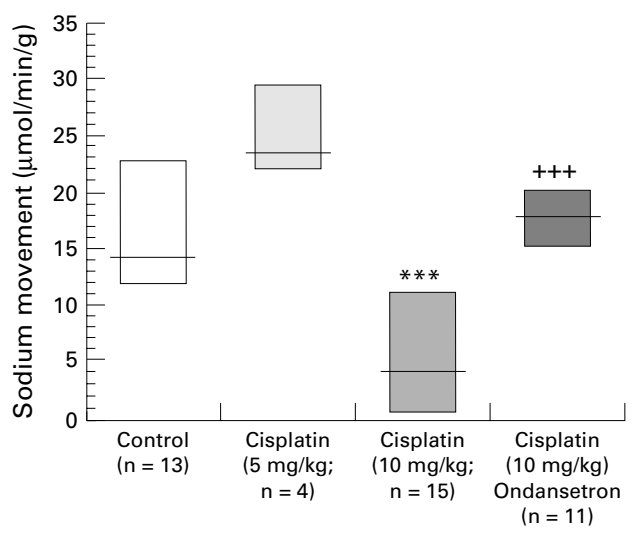

Figure 2 Net sodium movement (umol/min/g) in controls and animals treated with cisplatin or cisplatin and

ondansetron. Values are expressed as median (horizontal line) and interquartile range (bar). ${ }^{\star \star *} p<0.001$ compared with controls; $+t+p<0.001$ compared with cisplatin 10 $\mathrm{mg} / \mathrm{kg}$ alone but no different from controls.

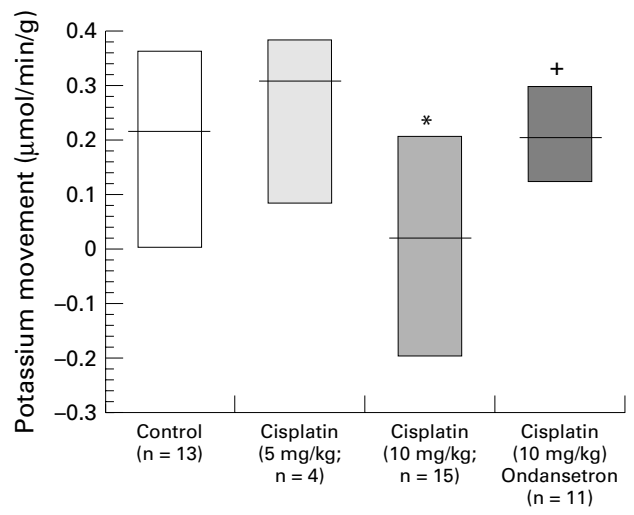

Figure 3 Net potassium movement $(\mu \mathrm{mol} / \mathrm{min} / \mathrm{g}$ ) in controls and animals treated with cisplatin or cisplatin and ondansetron. Values are expressed as median (horizontal line) and interquartile range (bar). ${ }^{\star} p<0.05$ compared with controls; $t p<0.05$ compared with cisplatin $10 \mathrm{mg} / \mathrm{kg}$ alone but no different from controls.

injection, the intestinal segment was perfused in situ with plasma electrolyte solution ( $\mathrm{Na} 140$ $\mathrm{mmol} / \mathrm{l}, \mathrm{K} 4 \mathrm{mmol} / \mathrm{l}, \mathrm{HCO}_{3} 40 \mathrm{mmol} / \mathrm{l}, \mathrm{Cl} 104$ $\mathrm{mmol} / \mathrm{l})$ containing $\left[{ }^{14} \mathrm{C}\right]$ polyethylene glycol 4000 (PEG) $4 \mu \mathrm{Ci} / 1$ and PEG $2 \mathrm{~g} / 1$ as non-absorbable volume markers. After an equilibration period of 30 minutes, to reach

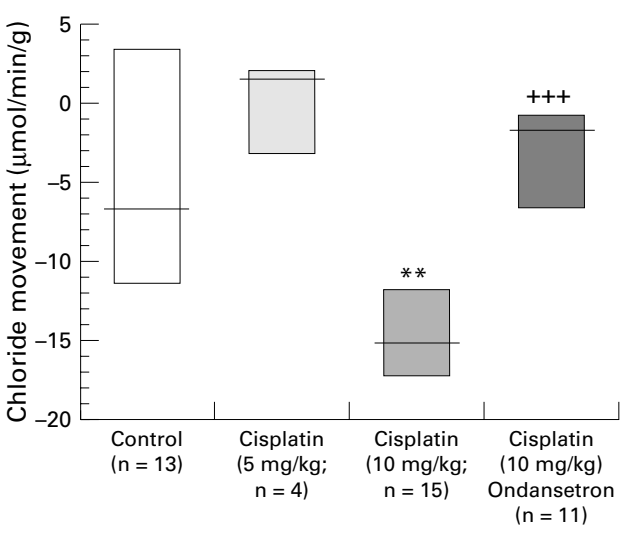

Figure 4 Net chloride movement $(\mu \mathrm{mol} / \mathrm{min} / \mathrm{g}$ ) in controls and animals treated with cisplatin or cisplatin and

ondansetron. Values are expressed as median (horizontal line) and interquartile range (bar). ${ }^{\star \star} p<0.01$ compared with controls; $++\dagger p<0.001$ compared with cisplatin 10

$\mathrm{mg} / \mathrm{kg}$ alone but no different from controls.

steady state, three separate 10 minute collections of the effluent were made. The experiment was repeated using subcutaneous ondansetron $300 \mu \mathrm{g} / \mathrm{kg}$ administered one hour before cisplatin. Control animals received the same volume of $0.9 \%$ saline subcutaneously. This dose of ondansetron is known to effectively block $5-\mathrm{HT}_{3}$ receptors, ${ }^{18}$ and we have shown previously that this dose will also reverse cholera toxin induced fluid secretion in rat small intestine, which is thought to be mediated, at least in part, by $5-\mathrm{HT}^{19}$ At the end of the experiment, $1-2 \mathrm{ml}$ blood was collected by intracardiac sampling, without replacement with intravenous fluid, and immediately centrifuged at $1500 \mathrm{~g}$ for 10 minutes at $4^{\circ} \mathrm{C}$. Specimens for histological examination were taken from the proximal half of the perfused and distal non-perfused bowel. Then, the ligated bowel was removed, stripped from the mesentery, dried in an oven for 24 hours and weighed so that the fluid and electrolyte transport results could be expressed per g dry intestinal weight. Finally the animals were killed by overdose with pentobarbitone. Platelet-poor plasma was stored at $-20^{\circ} \mathrm{C}$ before analysis of 5-HT by high performance liquid chromatography (HPLC). ${ }^{20}$

The specimens from control animals treated with intraperitoneal and subcutaneous saline and from animals treated with cisplatin 10 $\mathrm{mg} / \mathrm{kg}$ or cisplatin $10 \mathrm{mg} / \mathrm{kg}$ and ondansetron were fixed in $10 \%$ formol saline, embedded in paraffin wax, sectioned and stained with haematoxylin and eosin and examined by a histopathologist (P D) in a blinded fashion. The histological sections were $4 \mu \mathrm{m}$ thick. Two samples about $0.25 \mathrm{~cm}$ wide were taken from each animal, one from perfused small intestine and the other from the distal non-perfused small intestine. Each sample was divided into 8-10 sections from throughout the specimen.

ANALYTICAL PROCEDURES AND CALCULATION OF RESULTS

The $\left[{ }^{14} \mathrm{C}\right] \mathrm{PEG}$ concentration of each sample was measured in triplicate by liquid scintillation spectroscopy using an LKB 1912 liquid 
scintillation counter. Values were only accepted if recovery of radioactive PEG for each of the animals fell between 95 and $105 \%{ }^{21}$; any samples with reduced recovery were excluded. The concentration of sodium and potassium in small bowel effluent was measured by flame photometry using an Instrumentation Laboratory IL 943 and chloride on a Corning 945
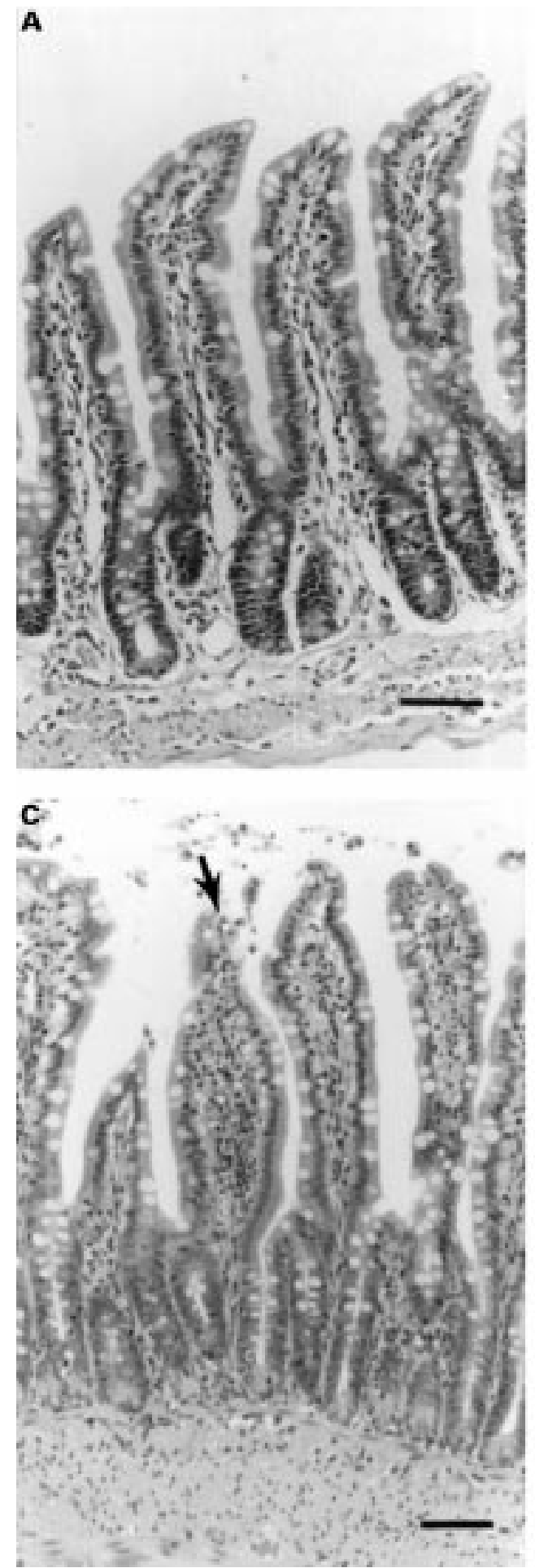

chloride meter. 5-HT was analysed in small bowel effluent, and platelet-poor plasma by HPLC with fluorimetric detection. ${ }^{20}$

Net fluid transfer is expressed in $\mu 1 / \mathrm{min} / \mathrm{g}$ dry intestinal weight, and net electrolyte transfer in $\mu \mathrm{mol} / \mathrm{min} / \mathrm{g}$ dry intestinal weight. Net absorption of fluid or electrolytes is indicated by a positive value, and net secretion by a negative
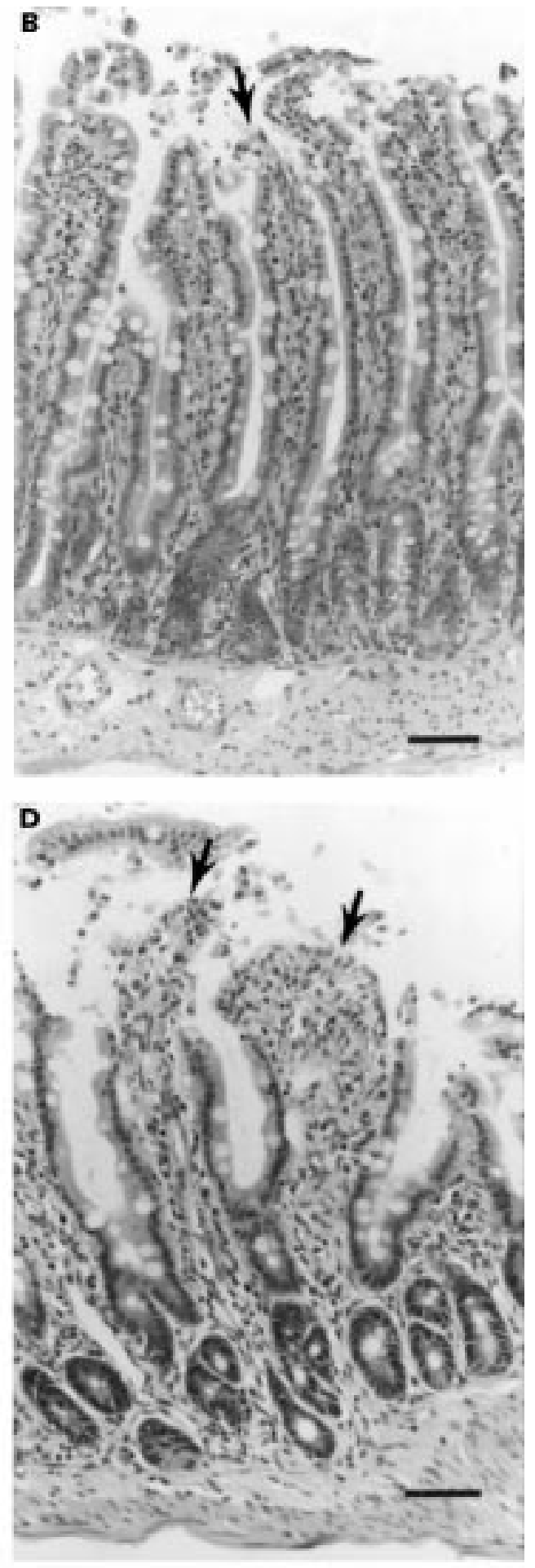

Figure 5 Histological sections from $(A)$ controls, $(B)$ cisplatin $(10 \mathrm{mg} / \mathrm{kg})$ treated animals and $(C)$ animals treated with cisplatin $10 \mathrm{mg} / \mathrm{kg}$ and ondansetron $300 \mu \mathrm{g} / \mathrm{kg}$ showing degeneration of the tips of the villi and enterocyte damage (arrows). These sections were selected to be representative of the histological appearance for each of the groups. An example of more serious damage after treatment with cisplatin $10 \mathrm{mg} / \mathrm{kg}$ is shown in (D), with denudation of the distal third of some of the villi which occurred in $23 \%$ of villi in one out of nine animals and was not present in all sections. All sections were examined in a blinded fashion but were 'selected' to be representative of the histology in each of the treatment groups. Bar $=100 \mu \mathrm{m}$. 
Table 1 Villus damage in rats treated with cisplatin or cisplatin and ondansetron

\begin{tabular}{|c|c|c|c|c|}
\hline Group & $\begin{array}{l}\text { Total no villi } \\
\text { examined } \\
\text { (a) }\end{array}$ & $\begin{array}{l}\text { Total no villi } \\
\text { damaged (b) }\end{array}$ & $\begin{array}{l}\text { Overall villus } \\
\text { damage } \\
(\text { b/a } \times 100 \%)\end{array}$ & $\begin{array}{l}\text { Median } \\
(I Q R) \% \\
\text { villus damage }\end{array}$ \\
\hline Control $(n=6)$ & 465 & 0 & 0 & $(0-0)$ \\
\hline Cisplatin $10 \mathrm{mg} / \mathrm{kg}(\mathrm{n}=9)$ & 1353 & 80 & 5.9 & $(0-7.9)$ \\
\hline \multirow{2}{*}{$\begin{array}{l}\text { Cisplatin } 10 \mathrm{mg} / \mathrm{kg} \text { plus ondansetron } \\
(\mathrm{n}=10)\end{array}$} & & & & \\
\hline & 1432 & 119 & 8.3 & $1.3(0-3.2)^{\star}$ \\
\hline
\end{tabular}

${ }^{\star} \mathrm{p}>0.5$ compared with cisplatin alone.

$\mathrm{IQR}$, interquartile range.

value. Effluent and plasma $5-\mathrm{HT}$ is expressed in $\mathrm{nmol} / \mathrm{l}$.

CHEMICALS

Cisplatin was obtained from Pharmacia \& Upjohn, Milton Keynes, Bedfordshire, UK, and ondansetron from Glaxo, Greenford, Middlesex, UK. $\left[{ }^{14} \mathrm{C}\right]$ PEG 4000 was obtained from Amersham International, Amersham, Buckinghamshire, UK, and all other chemicals were from BDH, Poole, Dorset, UK.

\section{STATISTICAL ANALYSIS}

The results are expressed as median and interquartile ranges, as the values were not normally distributed, and groups were compared by two tailed Wilcoxon rank sum tests.

\section{Results}

NET FLUID AND ELECTROLYTE MOVEMENT

Cisplatin at $5 \mathrm{mg} / \mathrm{kg}$ had no effect on net fluid movement, but at $10 \mathrm{mg} / \mathrm{kg}$ it reduced median fluid absorption (67 (46 to 100 ) $\mu \mathrm{l} / \mathrm{min} / \mathrm{g}$ dry intestinal weight; $\mathrm{n}=15)$ compared with controls (120 (107 to 151); $\mathrm{n}=13$; $\mathrm{p}<0.001$ ) (fig 1). Similarly there was a significant reduction in net absorption of sodium (4.1 (0.5 to 11.0) $\mu \mathrm{mol} / \mathrm{min} / \mathrm{g})$, potassium (0.08 ( -0.20 to 0.20 ) $\mu \mathrm{mol} / \mathrm{min} / \mathrm{g})$ and chloride $(-15.6(-11.9$ to $-17.6) \mu \mathrm{mol} / \mathrm{min} / \mathrm{g}$ ) in comparison with controls $(\mathrm{p}<0.001, \mathrm{p}<0.05, \mathrm{p}<0.01$ respectively) (figs 2, 3 and 4).

Ondansetron completely reversed the reduction in net fluid absorption produced by cisplatin (161 (130 to 176$) \mu \mathrm{l} / \mathrm{min} / \mathrm{g} ; \mathrm{n}=11$; $\mathrm{p}<0.001)$. Similarly, net sodium (17.8 (15.2 to $20.1) \mu \mathrm{mol} / \mathrm{min} / \mathrm{g} ; \mathrm{p}<0.001)$, potassium $(0.20$ $(0.12$ to 0.29$) \mu \mathrm{mol} / \mathrm{min} / \mathrm{g} ; \mathrm{p}<0.05)$ and chloride movement $(-1.8(-6.7$ to -1.1$) \mu \mathrm{mol} /$ $\mathrm{min} / \mathrm{g} ; \mathrm{p}<0.001)$ were also normalised. Fluid and electrolyte movement in animals treated with ondansetron and cisplatin were not significantly different from controls.

Recovery of $\left[{ }^{14} \mathrm{C}\right]$ PEG after treatment with cisplatin $10 \mathrm{mg} / \mathrm{kg}$ (98.3 (96.0 to 99.0$) \%$ ) was not significantly different from that in controls (97.2 (96.3 to 100.0$) \%$ ) or after treatment with cisplatin $5 \mathrm{mg} / \mathrm{kg}$ (96.2 (95.5 to 99.4$) \%$ ) or cisplatin $10 \mathrm{mg} / \mathrm{kg}$ and ondansetron (98.5 (96.5 to $99.0) \%$ ). In addition, median dry small intestinal weight after cisplatin $10 \mathrm{mg} / \mathrm{kg}(0.35(0.32$ to 0.41$) \mathrm{g}$ ) was also not significantly different from that in controls $(0.36(0.31$ to 0.53$) \mathrm{g})$ or after treatment with cisplatin $5 \mathrm{mg} / \mathrm{kg}(0.35$ $(0.27$ to 0.50$) \mathrm{g}$ ) or cisplatin $10 \mathrm{mg} / \mathrm{kg}$ and ondansetron (0.42 (0.34 to 0.46$) \mathrm{g}$ ).

5-HT IN INTESTINAL FLUID AND PLASMA

The 5-HT concentration in the jejunal effluent was below the level of detection in both the animals treated with cisplatin $10 \mathrm{mg} / \mathrm{kg}$ and in controls. The median platelet-poor plasma 5-HT was 19 (13 to 164$) \mathrm{nmol} / \mathrm{l}$ after cisplatin treatment which was not significantly different from that in control animals (18 (7 to 36) $\mathrm{nmol} / \mathrm{l})$.

SMALL INTESTINAL HISTOLOGY

Histological sections were taken from perfused small intestine and from the distal nonperfused small intestine. Once it was established that there were no histological differences between the perfused and non-perfused bowel, only the perfused bowel sections were used and photographed for this study.

Histological examination of sections from control animals injected with intraperitoneal saline and subcutaneous saline showed no abnormality (fig 5A, table 1 ). In those treated with cisplatin $10 \mathrm{mg} / \mathrm{kg}$, abnormal results were found in four of $59 \%$ of nine animals (patchy distribution, with mild to moderate degeneration of the distal ends of the villi and enterocyte damage, nuclear crowding, cytoplasmic vacuolation, and subepithelial apoptosis), although this was not seen in all sections (fig $5 \mathrm{~B}$, table 1 ). In the remaining five animals the histology was normal. Samples from animals treated with ondansetron and cisplatin (fig 5C, table 1) were indistinguishable from those treated with cisplatin alone, with damage in $8.3 \%$ of villi in five of ten animals examined. In one animal treated with cisplatin $10 \mathrm{mg} / \mathrm{kg}$ and one treated with cisplatin and ondansetron, there was more severe histological damage involving 23 and $9 \%$ of villi respectively. An example from the animal treated with cisplatin $10 \mathrm{mg} / \mathrm{kg}$ alone is shown in fig $5(\mathrm{D})$, with denudation of the distal third of the villi. There was no significant difference between the median (interquartile range) percentage of villi damaged in the cisplatin treated animals (0 (0 to 7.9$) \%)$ and the animals treated with cisplatin and ondansetron (1.3 (0 to 3.2)\%) ( $\mathrm{p}>0.5$, two-tailed Wilcoxon rank sum test).

\section{Discussion}

In the present study we have examined the possible involvement of 5-HT in cisplatin induced diarrhoea. We have shown that high dose cisplatin reduces net fluid and electrolyte absorption. This may be by decreasing absorption or by increasing secretion or a combination of the two. The 5- $\mathrm{HT}_{3}$ receptor antagonist ondansetron completely reversed the reduction in fluid and electrolyte absorption but did not protect cisplatin treated animals against mucosal damage.

The animal model used in this study was developed and validated by Rolston et al. ${ }^{21}$ The initial dose $(5 \mathrm{mg} / \mathrm{kg})$ of cisplatin was chosen as it was comparable with the usual human therapeutic dose of $1-3 \mathrm{mg} / \mathrm{kg}$ and because the pharmacokinetics of this dose have been studied in the rat. ${ }^{22}$ As this dose had no appreciable effect on intestinal fluid transport, $10 \mathrm{mg} / \mathrm{kg}$ was investigated. A dose-response effect of cisplatin had previously been noted by Cubeddu et $a l^{14}$ when studying urinary 5-HIAA in cancer patients. Cisplatin is thought to be absorbed by 
simple diffusion through the peritoneum, and no evidence has been found for active transport after ingestion of an oral dose. ${ }^{23}$ The intraperitoneal route was chosen for administration of cisplatin, as Vadiei et $a l^{2}$ showed no significant difference in plasma levels of cisplatin using the intraperitoneal and intravenous routes for the same $5 \mathrm{mg} / \mathrm{kg}$ dose, and intraperitoneal administration is technically easier. Peak serum levels were achieved $30 \mathrm{~min}$ after an intraperitoneal dose of cisplatin and peak tissue levels in the kidney were found after one hour. It was for this reason that the small bowel perfusion in the present study was delayed for one hour after administration of cisplatin. Control experiments were not performed with ondansetron alone, as Mourad et $a l^{19}$ had found that another $5-\mathrm{HT}_{3}$ receptor antagonist granisetron had no effect on basal fluid movement.

Although cisplatin treatment is associated with diarrhoea in $67 \%$ of patients, this is the first study on the effect of cisplatin on intestinal secretion and reversal by $5-\mathrm{HT}_{3}$ receptor antagonism. Cisplatin, in high doses, is associated with increased 5-HIAA in the urine in cancer patients. ${ }^{414}$ Gunning et $a l^{24}$ found raised levels of 5-HT and 5-HIAA in the gastric mucosa, and Endo et $a l^{25}$ found increased levels of 5-HT in the ileal mucosa of ferrets pretreated with cisplatin. Barnes et $a l^{26}$ measured increases in plasma 5-HT concentrations in some patients receiving cisplatin. Schworer et $a l^{15}$ found increased 5-HT and 5-HIAA release from isolated vascularly perfused guinea pig ileum, after intra-arterial administration of cisplatin; this effect was prevented by the neurotoxin, tetrodotoxin. Cisplatin may therefore have an indirect ability to release 5-HT from gut enterochromaffin cells via activation of a neuronal pathway. Schworer et $a l^{15}$ also showed that the $5-\mathrm{HT}_{3}$ receptor antagonist ondansetron antagonised the ability of cisplatin to increase 5-HT turnover, which suggested that $5-\mathrm{HT}_{3}$ receptor antagonists prevented cytotoxin induced emesis by both antagonising the action of $5-\mathrm{HT}$ at the $5-\mathrm{HT}_{3}$ receptor and inhibiting the release of 5-HT from the gut.

The mechanism by which cisplatin releases $5-\mathrm{HT}$ is unknown. The source of 5-HT released by cisplatin has been suggested by Cubeddu $e t a l^{4}$ to be the enterochromaffin cells of the gut, as there was no change in platelet 5-HT concentration after high dose cisplatin, despite marked plasma 5-HT fluctuations in cancer patients undergoing treatment with cisplatin. The in vitro work of Schworer et $a l^{15}$ suggests that there is prompt release of 5-HT from enterochromaffin cells on exposure to cisplatin. Physical disruption of cells appears later, so release of 5-HT is probably by normal exocytosis. Cisplatin bivalently bonds to the bases in DNA, inhibits DNA synthesis, and is cytolethal in all stages of the cell cycle; this is likely to be the mechanism of intestinal mucosal cell damage in this study. Severe mucosal damage of the ileum and jejunum followed treatment with high dose cisplatin in the ferret ${ }^{24}$ and the mouse, ${ }^{27}$ and, in breast cancer patients on combination chemotherapy, crypt cell vacuolation was observed. ${ }^{28}$ The reason why the villus damage was only observed in some animals treated with cisplatin or cisplatin and ondansetron may be differences between animals or sampling error.

In addition to effects that cisplatin induced 5-HT may have on gut function, cisplatin has been shown to be directly neuroexcitatory to cultured dorsal root ganglion cells. ${ }^{29}$ Cisplatin also caused transient stimulation of motility of stomach and upper small intestine in ferrets in vivo, which occurred earlier than the emetic response and was not blocked by ondansetron. ${ }^{30}$ It has also been shown, in the house musk shrew, that cisplatin induced emesis may be mediated by free radicals, and prevented by radical scavengers. ${ }^{31}$

The association of 5-HT and diarrhoea has been well established in the carcinoid syndrome, ${ }^{7}$ and 5 -HT is known to be an intestinal secretagogue in vivo ${ }^{16}$ and in vitro. ${ }^{32}$ Diarrhoea is a documented side effect in $67 \%$ of patients treated with cisplatin. ${ }^{1}$ Cunningham et $a l^{28}$ showed a non-significant reduction in fluid and electrolyte movement in patients undergoing chemotherapy with cyclophosphamide, 5-fluorouracil, and methotrexate for breast cancer. However, this is the first study to investigate intestinal transport changes in association with cisplatin treatment and to implicate the $5-\mathrm{HT}_{3}$ receptor in these changes. We did not show 5-HT release into jejunal effluent or plasma, although the 5 -HT-emesis hypothesis ${ }^{33}$ emphasises that 5-HT from enterochromaffin cells is released and acts locally on $5-\mathrm{HT}_{3}$ receptors situated on afferent vagal nerve terminals. Activation of these receptors could influence secretion via a neuronal mechanism, possibly involving vasoactive intestinal peptide release. ${ }^{34}$ Using the cholera model of secretion, ${ }^{8}$ released 5-HT may also activate $5-\mathrm{HT}_{2}$ receptors situated on the enterochromaffin cells and the mucosal cells, ${ }^{35}$ causing secretion via release of prostaglandins. ${ }^{10}$

We have shown therefore that high dose cisplatin reduces jejunal net fluid and electrolyte absorption in the rat in vivo. Although intestinal histological damage in the cisplatin treated animals was marked, the $5-\mathrm{HT}_{3}$ receptor antagonist ondansetron reversed the reduced absorption to normal, suggesting that 5-HT is involved in the intestinal transport process.

C P B was supported by an Alimentary Pharmacology and Therapeutics Trust/ British Digestive Foundation Fellowship.

1 Kris M, Gralla R, Clark R, et al. Control of chemotherapyinduced diarrhoea with a synthetic enkephalin BW942C: a randomised trial with placebo in patients receiving cisplatin. F Clin Oncol 1988;6:663-8.

2 Fozard J. 5- $\mathrm{HT}_{3}$ receptors and cytotoxic drug-induced vomiting. Trends Pharmacol Sci 1987;8:44-5.

3 Blower P. The role of specific 5-HT ${ }_{3}$ receptor antagonism in the control of cytostatic drug-induced emesis. Eur f Cancer 1990;26(suppl 1):S8-11.

4 Cubeddu L, Hoffmann I, Fuenmayor N, et al. Efficacy of ondansetron (GR 38032F) and the role of serotonin in cisplatin-induced nausea and vomiting. $N$ Engl $7 \mathrm{Med}$ 1990;322:810-16.

5 Miner W, Sanger G. Inhibition of cisplatin-induced vomiting by selective 5-hydroxytryptamine M-receptor antagonism. Br F Pharmacol 1986;88:497-9.

6 Anderson J, Coupe M, Morris J, et al. Remission of Anderson J, Coupe $M$, Morris J, et al. Remission of
symptoms in carcinoid syndrome with a new symptoms in carcinoid syndrome with a new
5-hydroxytryptamine $M$ receptor antagonist. $B M \mathcal{F} 1987$; 294:1129. 
7 Donowitz $\mathrm{M}$, Binder $\mathrm{H}$. Jejunal fluid and electrolyte secretion in carcinoid syndrome. Am 7 Dig Dis 1975;20. secretion

8 Beubler E, Kollar G, Saria A, et al. Involvement of 5-hydroxytryptamine, prostaglandin $\mathrm{E}_{2}$, and cyclic adenosine monophosphate in cholera toxin-induced fluid secretion in the small intestine of the rat in vivo. Gastroenterology 1989;96:368-76

9 Bearcroft CP, Perrett D, Farthing MJG. 5-Hydroxytyptamine release into human jejunum by cholera toxin. Gut 1996;39:528-31.

10 Beubler E, Horina G. 5- $\mathrm{HT}_{2}$ and 5- $\mathrm{HT}_{3}$ receptor subtypes mediate cholera toxin-induced intestinal fluid secretion in the rat. Gastroenterology 1990;99:83-9.

11 Sjoqvist A, Cassuto J, Jodal M, et al. Actions of serotonin antagonists on cholera toxin-induced intestinal fluid secretion. Acta Physiol Scand 1992;145:229-37.

12 Turvill JL, Farthing MJG. Effect of granisetron on cholera toxin-induced enteric secretion. Lancet 1997;349:1293.

13 Beubler E, Bukhave K, Rask-Madsen J. Significance of calcium for the prostaglandin $\mathrm{E}_{2}$-mediated secretory response cium for the prostaglandin $\mathrm{E}_{2}$-mediated secretory response to 5-hydroxytryptamine
ology $1986 ; 90: 1972-7$.

14 Cubeddu L, Hoffmann I, Fuenmayor N, et al. Changes in serotonin metabolism in cancer patients: its relationship to nausea and vomiting induced by chemotherapeutic drugs. Br F Cancer 1992;66:198-203.

15 Schworer H, Racke K, Kilbinger H. Cisplatin increases the release of 5-hydroxytryptamine (5-HT) from the vascularly perfused small intestine of the guinea-pig: involvement of 5-HT receptors. Naunyn-Schmiedebergs Arch Pharmacol 1991; 344:143-9.

16 Donowitz M, Charney A, Hefferman J. Effect of serotonin treatment on intestinal transport in the in vivo rabbit small intestine. Am $\mathcal{F}$ Physiol 1977;232:E85-94.

17 Hardcastle J, Hardcastle P, Redfren J. Action of 5 -hydroxytryptamine on intestinal ion transport in the rat. F-hydroxytryptamine on intes

18 Butler A, Hill J, Ireland S, et al. Pharmacological properties of GR38032F, a novel antagonist at 5- $\mathrm{HT}_{3}$ receptors. $\mathrm{Br}$ Pharmacol 1988;94:397-412.

19 Mourad FH, O'Donnell LJD, Dias J, et al. Role of 5-hydroxytryptamine type 3 receptors in rat intestinal fluid and electrolyte secretion induced by cholera toxin and Escherichia coli enterotoxins. Gut 1995;37:340-5.

20 Bearcroft CP, Farthing MJG, Perrett D. Determination of 5-hydroxytryptamine, 5-hydroxyindoleacetic acid and tryptophan in plasma and urine by HPLC with fluorimetric detection. Biomed Chromatogr 1995;9:23-7.

21 Rolston D, Borodo M, Kelly M, et al. Efficacy of oral rehydration solutions in a rat model of secretory diarrhoea. $f$ Paediatr Gastroenterol Nutr 1987;6:624-30.
22 Vadiei K, Siddik Z, Khokhar A, al-Baker S, et al. Pharmacokinetics of liposome-entrapped cis-bisneodecanoato-trans-R,R-1,2-diaminocyclohexane platinu$\mathrm{m}$ (II) and cisplatin given i.v. and i.p. in the rat. Cancer Chemother Pharmacol 1992;30:365-9.

23 Binks S, Dobreta M. Kinetics and mechanism of uptake of platinum-based pharmaceuticals by the rat small intestine. Biochem Pharmacol 1990;40:1329-36.

24 Gunning S, Hagan R, Tyers M. Cisplatin induces biochemi$\mathrm{cal}$ and histological changes in the small intestine of the ferret. Br f Pharmacol 1987;90:135P.

25 Endo T, Minami M, Monma Y, et al. Emesis-related biochemical and histopathological changes induced by cisplatin in the ferret. F Toxicol Sci 1990;15:253-44.

26 Barnes N, Ge J, Jones W, Naylor R, Rudd J. Cisplatininduced emesis: preliminary results indicative of changes in plasma levels of 5-hydroxytryptamine. $\mathrm{Br} \quad \mathrm{f}$ Cancer 1990;62:862-4

27 Allan S, Smyth J. Small intestinal mucosal toxicity of cis-platinum: comparison of toxicity with platinum analogues and dexamethasone. Br f Cancer 1986;53:355-60.

28 Cunningham D, Morgan R, Mills P, et al. Functional and structural changes of the human proximal small intestine after cytotoxic therapy. $\mathcal{F}$ Clin Pathol 1985;38:265-70.

29 Scott R, Manikon M, Andrews PLR . Actions of cisplatin on the electrophysiological properties of cultured dorsal root ganglion neurones from neonatal rats. NaunynSchmiedeberg's Arch Pharmacol 1994;349:287-94.

30 Davidson H, Andrews PLR. Stimulation of gastrointestinal motility by cisplatin in the ferret: activation of an intrinsic cholinergic mechanism dissociated from emesis. NaunynSchmiedeberg's Arch Pharmacol 1993;347:506-13.

31 Toril Y, Mutoh $\mathrm{M}$, Saito $\mathrm{H}$, et al. Involvement of free radicals in cisplatin-induced emesis in Suncus murinus. Eur f Pharmacol 1993;248:131-5.

32 Donowitz M. Ca ${ }^{++}$in the control of active intestinal $\mathrm{Na}$ and $\mathrm{Cl}$ transport: involvement in neurohumoral action. $\mathrm{Am} \mathcal{F}$ Physiol 1983;245:G165-77.

33 Andrews PLR, Rapeport W, Sanger G. Neuropharmacology of emesis induced by anti-cancer therapy. Trends Pharmacol Sci 1988;9:334-41.

34 Cassuto J, Jodal M, Tuttle R, et al. 5-hydroxytryptamine and cholera secretion. Physiological and pharmacological studies in cats and rats. Scand $\mathcal{F}$ Gastroenterol 1982;17:695703 .

35 Siriwardena A, Smith E, Borum E, et al. Identification of a 5-hydroxytryptamine $\left(5-\mathrm{HT}_{2}\right)$ receptor on guinea pig small intestinal crypt cells. Am f Physiol 1993;265:G339-46. 